\title{
Reflections on emerging horse and rider relationship: Media relations between Zimbabwe and China.
}

\author{
Golden Maunganidze ${ }^{1}$, Innocent F. Chiyadzwa ${ }^{2}$ and David Tobias ${ }^{3}$ \\ 1. Great Zimbabwe University, Masvingo, Zimbabwe, \\ 2. Great Zimbabwe University, Masvingo, Zimbabwe, \\ 3. Great Zimbabwe University, Masvingo, Zimbabwe,
}

\begin{abstract}
Colonialism and imperialism have several facets and in the global world systems which take into consideration political, economic and social domination, China is questioned for her quiet diplomacy and generosity in donating to the Zimbabwean media. The relationship between China and Zimbabwe has a long history which dates back to the liberation struggle when China rendered material and financial assistance. Upon the attainment of independence the relationship assumed a new dimension where China is striving to dominate the continent through manipulating the media. This paper seeks to explore strategies and techniques employed by China to control and influence media content in Zimbabwe. After being shunned by Western countries for its 'bad governance', Zimbabwe vigorously campaigned for a 'Look East' policy that ended up reviving and strengthening her ties with China. China donated critical broadcasting equipment, agricultural equipment and loans to revive the Zimbabwean economy which had seriously been ravaged by sanctions. Against this backdrop this paper therefore argues that the friendship between China and Zimbabwe is characterised by a horse and a rider relationship. Drawing examples from documentary evidence, the paper exposes the dominance of China in the media through training of personnel, exchange programs and donations. Key words: Colonialism, Horse-rider relationship, Imperialism, Look East Policy, Private media, Public media.
\end{abstract}

\section{Introduction}

"Media co-operation between Africa and China will allow Africa to pursue an independent media policy founded on mutual respect and reciprocal concession.... Africa's media relations with China must not seek to reproduce the asymmetry that existed between Africa and the West.... with digitalisation, we should be able to carry on a reciprocal basis channels from each other's sub-continents so (sic) our civilisations interact continually as equals". The foregoing epigram by the Minister of Media, Information and Publicity Webster Shamu reflects the naïve and probably misconstrued notion that Zimbabwe and China operate at the same wavelength yet pointers are that of a horse and a rider relationship with China riding and Zimbabwe being the horse. The above statement is reflective and representative of the view of the Zimbabwean government. A careful analysis of the available evidence indicates that such notions are not a true reflection of the reality on the ground. This paper strives to challenge such an assertion by highlighting cases from the media to prove that the relationship between China and Zimbabwe is that of a horse and a rider. Therefore the purported friendship is not symbiotic but rather parasitic in nature. Taken in this context such relations need to be revisited by policy makers.

The relations between Zimbabwe and China emanated from the liberation struggle with nationalist political parties, the Zimbabwe African National Union Patriotic Front (ZANU PF) and the Zimbabwe African Peoples Union (ZAPU) adopting a Maoist- ideology (Prew etal 1993,116). During these days the Chinese taught the liberation movements guerrilla warfare in 'earnest' and had no ambitions to conquer the economies of the third world. During the liberation war the Chinese provided weapons thus they became endeared to the nationalists. The victory against colonialism in Zimbabwe thus is attributed partly to the contributions of the Chinese ideology (Mpofu et al 2009,193).

It is from this background that the relations between the two countries are dubbed, 'all weather friends' since the Chinese are perceived as having been there during the fight for self- determination and also when Zimbabwe came under attack from the West from the year 2000 to date. The open door policy of China of ever accommodating Zimbabwe raises eyebrows as questions as to 'what's in for the Chinese and in whose best interest are they serving, should be asked'.

The year 2000 marks a turning point in the history of Zimbabwe as it saw the country embarking on the Fast Track Land Reform which resulted in the country being heavily criticised for paying no regard to the rule of law and abuse of human rights by international community. The birth of the opposition party, Movement for Democratic Change (MDC) and the imposition of sanctions dubbed targeted sanctions on the country as well as the voluntary withdrawal of Zimbabwe from the Commonwealth countries made Zimbabwe to be in a very 
difficult situation owing to isolation and serious economic down- turn.. It is during this time that the country in order to avert being a pariah state looked 'East' and reignited the flame with the all-weather friend China. Like in the liberation struggle the all weather friend was accommodative and supportive pledging interest free loans, investment and above all 'not to interfere with Zimbabwe's internal politics' (The Herald September 2004). From this brief background it can be asserted that the relations between China and Zimbabwe though claimed to be equal, are heavily tilted in favour of the Chinese.

This paper argues that the Chinese filled the neo-colonial void left by the British and her western allies in most economic sectors when relations between Zimbabwe and Britain got strained. A look at the general contributions of the Chinese in the economy will be explored first before a thorough analysis of the strategies being used to control and dominate Zimbabwe's media to prove the imperial and neo-colonial agenda of China.

\section{Chinese hand in Zimbabwe's economy}

Generally, the relationship between China and Africa has been seen in the economic field particularly after the attainment of independence. She however had become a major contender in the 1960's and 1970's as part of its ideological rivalry with the Soviet Union. In this she had supported certain military movements like National Union for the Total Independence of Angola (UNITA) but ultimately she made efforts to have access to oil assets. Taken in that context her efforts in delivering arms were expected to be rewarded by economic gains (Burges etal 2006,303). A careful analysis of China in this regard is not different from Western powers like Britain, France and United States of America which have used whatever means and influence to access African resources. In other words they have used economic incentives, diplomacy, provision of arms and military hardware as means at their disposal to secure the world for their own investments.

In the Zimbabwean context the relationship between China and Zimbabwe should be understood in the growing Chinese economy particularly between the year 2000 to 2005 . There was need for raw materials in China (Burges etal 2006,303). In the same vein Zimbabwe's Look East Foreign Policy was officially launched by Zimbabwean President Robert Gabriel Mugabe on 6 December 2005. This took place when he delivered the state of the nation address to the parliament of the Republic of Zimbabwe (Mudyanadzo 2011,147) Over the years reports on the relationship of Zimbabwe particularly through the state-controlled newspaper, The Herald, have portrayed mutual complementality, trust and respect. China was commended for supporting Zimbabwe materially and morally on one hand, whilst on the other hand Zimbabwe openly and strongly supported the sovereignty and territorial integrity of China (Muzondidya 2011,148). To this effect Zimbabwe supported the fact that the two provinces of Taiwan and Tibet should be treated as part of mainland China.

The available evidence indicates that China has shown keen interest in developing the Zimbabwean economy especially in the mining and agricultural sectors. She embarked on joint mining projects with state companies in Zimbabwe, giving an impression of a mutual and beneficial relationship between the two countries.

According to media reports, China supplied Air Zimbabwe with three MA60 aircraft in 2005 and 2006, a time when Air Zimbabwe was facing serious viability challenges. It was purportedly facing serious economic difficulties due to the imposition of sanctions by the West. Due to such development it was very difficult for Zimbabwe to render services to its local and regional markets. Taken in this context the forged co-operation resulted in Zimbabwe managing to build and revive its regional aviation hub (Muzondidya 2011,148).

Furthermore, due to this co-operation and assistance, the available evidence indicates that Air Zimbabwe could now fly to Bulawayo, Victoria Falls, Joburg, Lilongwe and Lubumbashi. In addition 135 conventional buses and 41 mini buses were supplied to the Zimbabwe United Passenger Company (ZUPCO) (Muzondidya 2011,149) The fact that the replenishment of the ZUPCO fleet with the Chinese assistance should not be overemphasized. More assistance from China is said to have been realized especially in 2006. According to The Herald of 19 January 2006 Zimbabwe benefitted in so many ways. The national sports stadium and Magamba hockey stadium and Chinhoyi Hospital were all built with the help of technical co-operation from China. More to that schools, roads, agricultural demonstration, centres and more humanitarian programmes were put in place.

Another development had already taken place when the two countries entered into an agreement which was called the Zimbabwe, China Business Council (ZCBC) was officially launched by the Zimbabwean Vice President Joyce Mujuru and the former Chinese ambassador Zhang Xianyi at the Harare International Conference Centre (HICC) among other issues they agreed to promote trade between Zimbabwe and China (The Herald 10 September 2004). In this Zimbabwe was given opportunities to establish investments in China. Zimbabwe also owing to this development managed to participate at the China International Fare/ for trade investments (CIFTI) from the $8^{\text {th }}$ to the $11^{\text {th }}$ of September 2006. Owing to this agreement Zimbabwe managed to penetrate Chinese markets and financial investments (The Herald 15, Nov 2006)

It has been argued that more assistance was given to Zimbabwe in terms of equipment for the rural electrification programmes. More help came in the form of humanitarian aid especially in 2005 when 3000 tonnes of maize to alleviate food shortages were donated(Muzondidya 2011,149).Although the bilateral 
relationship between the two countries are said to have grown from strength to strength, this arrangement has failed to meaningfully create a robust economy on the side of Zimbabwe. The authors of this paper argue that China is in business to make money not only in Zimbabwe but on the whole continent. Thus it is quick to note that the idea of emphasizing historical ties is only relevant if it is translated into business opportunities and growths of her economy.

Zimbabwe has failed to meaningfully obtain cheaper offshore funding or credit lines from China as provided under the Beijing Action plan of 2007-2009 (Muzondidya 2011,151 ). China has criticised Zimbabwe for failing to fulfil some of the terms enshrined in the agreement. Whatever the case may be it should be noted that China has initiated a policy termed "going global strategy" (Muzondidya 2011,15) Through this strategy China is aiming to create hubs for capital investments. She is seriously considering entering Mozambique, Angola, Tanzania and Uganda. Against this backdrop it is quick to note that China' approaches are determined by economic considerations. She is mainly tapping economic resources for her growing economies. As a result she has become an imperialist. Her relationship with Zimbabwe is not very strong because she is committed elsewhere.

According to The Herald, 5 May 2010 China is accused of dumping shoddy products to Africa in general and to Zimbabwe in particular. These products in most cases are very cheap and locally manufactured. These have attracted the great market drawn mainly from the poor and the low-income earners. As a result the local industries have been adversely affected by losing their market base. Some industries especially those which deal with clothing and textiles products have encountered stiff competition from Chinese firms. Due to such challenges they have decided to close down. Thus Zimbabwe's relations with China have failed to meaningfully produce the desired results. That being the case, it is important to note that Zimbabwe entered into bilateral trade agreements with China out of desperation. The West had imposed sanctions and the economy was having a down-turn, as has been cited elsewhere in this paper. Therefore to come out of the isolation, the Look East Policy was adopted to break the West's economic stranglehold on Zimbabwe (Thomson 2004,175). Thus Zimbabwe has no choice but to accept a better devil. Even Gaddafi of Libya, a champion of anti-western African government had reduced his association with Zimbabwe (Thomson 2004,175). The effects of isolation on Zimbabwe should not be overemphasised. Zimbabwe has been desperate for capital and has tried to secure at the expense of resources like minerals. The resources of Zimbabwe are no longer used to enhance Zimbabwe's industrialization, economic growth and infrastructural development. Taken in this context China has actually become an imperialist because she is focusing on taping the resources of Africa for her own advantages.

On another note, the majority of Zimbabweans do not speak the Chinese language, as a result, it is very difficult to comprehend the Chinese culture of business, beliefs and attitude which affect business practices. Thus the bilateral agreements have remained hallow though China is benefiting from the raw materials (Thomas 2004,154). China has become a colonialist seeking natural resources in exchange for capital.

\section{China-Zimbabwe media relations}

The China-Zimbabwe relations in radio transmission and communication techniques date back to the 1970s when the two liberation movements in the country namely the Zimbabwe National Liberation Army (ZANLA) and the Zimbabwe People's Revolutionary Army (ZIPRA) got training in guerrilla warfare from China. When the country attained independence in 1980 the relationship between the two countries became salient and it was taken for granted that there was co-existence between the two countries. It was until the year 2000 that the media in Zimbabwe started to cover the relations between the two countries seriously with the media reporting differently on the nature and intention of Chinese contributions in the country. The media in Zimbabwe showed polarisation when reporting on China just like they do with the two major political parties, Zanu PF and MDC. An understanding of the media in Zimbabwe is imperative for an appreciation of the editorial and differential coverage perspectives of the press in issues relating to China.

\section{The history of media in Zimbabwe}

The history of the media in Zimbabwe is well documented from the colonial era to the present, ( Windrich 1981,15) ( Fredrikse 1982, 104), (Rusike 1990,17), (Saunders 1991,27) ( Mararike 1993, 51) ( Mathema 2000,14 ) and (Chari 2011,367). As such this paper shall not belabour it but highlight major players in the sector.

The media in terms of ownership is divided into publicly owned and privately owned media. The Zimbabwe Newspapers (Zimpapers) which are publicly owned by the state dominates the print media in the country. The recent Zimbabwe All Media Products Survey (ZAMPS) showed that Zimpapers' The Sunday Mail is the best selling Sunday paper in the country while its sister paper The Herald is again rated the best daily paper in terms of readership (The Herald February 28, 2013). Zimpapers also owns Star FM radio station. Although the majority of Zimbabweans do not solely depend on the public media for news, the fact that the media industry is flooded with products from the public media automatically leaves the major news products 
consumed coming from those that dominate the industry. The privately owned newspapers such as the News Day, The Daily News and various online publications can be accessed by every Zimbabwean but they are facing tough competition from the public owned media organisations.

There is no privately owned television station in the country hence Zimbabwe Broadcasting Holdings $(\mathrm{ZBH})$ which has two television stations is left without any competitor. The Broadcasting Services Act of Zimbabwe Chapter 12:06 of 2001 outlaws any foreign funding, ownership or donation of equipment by foreigners for a broadcasting project in Zimbabwe. This has deterred locals from investing in broadcasting sector. People who prefer diversity should be rich enough to spare an extra dollar for subscribing to pay television station where they can access different voices. However, often channels accessed on pay television stations are mainly focusing on other countries and they would come to Zimbabwe when there is a major event that appeals to many countries.

The media in Zimbabwe requires revenue from advertisers in order to survive. Some private newspapers do not reach to all parts of the country citing logistical problems mainly emanating from lack of funding. This has seen newspaper distribution in the country mainly following tarred roads, main townships, Growth Points and urban centres. However, papers from the Zimpapers stable especially The Sunday Mail can be found far from urban centres. Besides Zimpapers, the Zimbabwean government through the Zimbabwe Mass Media Trust runs New Zimbabwe Inter Africa News Agency (New-Ziana). Besides a News Agency, New Ziana also runs community newspapers throughout the whole country. There are at least ten community newspapers under New-Ziana, one servicing a particular province.

It is against this background that China came in to support public owned media to boost her image both in Zimbabwe and beyond. Since 2000, China has been forging partnerships with the public media, entering into several deals, exchange programs and donating critical equipment to both Zimpapers and the Zimbabwe Broadcasting Holdings. Although it has never announced, China's interest in funding Zimbabwean media should never be underestimated but it calls for a serious critic to ascertain whether the former is just donating generously or trying to dive on an unsuspecting prey whose appetite for donations will attract disastrous consequences sooner or later.

\section{Strategies employed by China to influence the media in Zimbabwe}

China from the year 2000 has taken a multi-pronged approach in ensuring that its hand was active in the Zimbabwean media apart from stationing its journalist from Xinhua news agency to news gather in the country's territory. The key strategies employed are:

\section{Training and sponsorship of media practitioners}

Several journalists from Zimpapers and the New Ziana went to China for training. During the training in China the journalists are exposed and conscientised about the heritage and cultural sites thereby marketing the Chinese. Training by its nature is ideological thus the other reason for the Chinese government to sponsor such trainings is to influence content and newsgathering in a manner that is consistent with their expectations. The fact that China became a prominent trainer after the voluntary withdrawal of Zimbabwe from the Commonwealth highlights that China is simply filling the colonial void left by the West. In actual sense the Chinese are striving to deconstruct the western style journalism training methods used in the country to their own style. To show the unbalanced relationship where the other partner seem to be more powerful and allknowing China does not export its journalists to be trained by Zimbabwean counterparts in the training institutions. Thus while Zimbabweans are flooding China media training institutions for Chinese sponsored diploma to post-graduate studies, there is no reciprocal training in Zimbabwe.

\section{Exchange visits by Newsroom Managers}

Prominent editors from China have been visiting the country and 'exchanging notes' with group editors in the country's public media. A case in point is when Xinhua News Agency editor-in-chief He Ping and a delegation of six others visited Zimpapers group editor-in-chief Pikirayi Deketeke in August 2012. Commenting on Zimpapers, He Ping urged Zimpapers to stay abreast with technological developments and to pay closer attention to and adopt latest trends in communication technologies that constitute the new media platforms. The implications and influence of such visits are evidenced by Zimpapers' defence of China as a friend and a coloniser. In an article published by The Herald on October 1, 2012 titled China ain't colonising Zimbabwe, the paper is at pains to extricate China from its neo-colonial 'mission.'

\section{Media Bi-lateral Agreements and Donations}

Zimbabwe and China have entered into media bilateral agreements with China. There is an agreement between New Ziana and Xinhua news agency. There is also a bilateral agreement between China radio and 
Zimbabwe Broadcasting Holdings. China has donated digital broadcasting equipment to the sole national broadcaster the Zimbabwe Broadcasting Holdings. It also donated an outside broadcasting van.

\section{Presentation and representation of China in the Media}

Since 2000, China's presence in Zimbabwean media was growing at an alarming rate. Although the private media was hitting hard on China equating her to Zimbabwe's new colonial master, the public media however, spoke on behalf of China defending all the deals signed by the two countries. Taking from the private media's perspective, Zimbabwe which was enjoying the Western 'guardianship' for two decades still felt that it was not yet able to stand alone and sought another master in the East who would give moral, financial as well as material support especially when the West proved to be hostile to her former colony.

It's ironic today that those who claim to have fought the liberation struggle and declaring that "Zimbabwe will never be a colony again" are actually aiding the colonisation of the country by the Chinese. It is no secret that the Chinese have taken over most of the lucrative diamond and other mines and are benefitting more than the Zimbabweans who are supposed to be the beneficiaries of the country's mineral wealth. (The Zimbabwean 26 June 2012).

The argument from The Zimbabwean was based on the fact that despite China being seen to be a new hope for an ailing ordinary Zimbabwean, the reality of the matter was that Chinese nationals were in the country for their own selfish benefit. Just like how the local chiefs like Lobengula were selfish in selling the land to the British colonisers for their personal benefit, the article titled Zimbabwe fast becoming a Chinese colony in The Zimbabwean of June 26, 2012 argue that an ordinary Zimbabwean is still suffering while the top government officials were enjoying the selfish benefits of befriending China.

Our roads are still characterised by potholes and dilapidation, many go hungry and street kids are a common feature. Unemployment is still very high and the economy is still not robust enough for the country to use its own currency. What benefit are these Chinese deals bringing and what development has been spurred by their coming to Zimbabwe? (The Zimbabwean 26 June 2012).

In a clear illustration of the extent to which the country was slowly but surely getting colonised by China, The Zimbabwean further argues that a lot of sign-posts are either being seen in the former coloniser's language English or the new master's language Chinese. When the British came into Zimbabwe, they were quick to introduce their religion and language.

There is nothing so telling of colonialism than Zimbabweans ignoring their own languages like Shona and Ndebele and writing signboards at our airports in Chinese.( The Zimbabwean 26 June 2012).

They also kept praising the local leadership in order to continue getting favours from those who were in power. The formula which worked for Britain about 100 years ago seem to be working again for China who has spread her colonial wings over almost every critical area in Zimbabwe. In 2012, China had the temerity to build its place of worship at one of the most special place in Zimbabwe - Chiyadzwa diamond mining area. If there was any religious structure that would be erected near or at Chiyadzwa mining area, one would logically think that it would be an African traditional hut for the elders to perform their rituals as a way of thanking ancestors for providing a precious stone (diamonds) to the Zimbabweans. However, the government allowed the Chinese to build a Jin'an Buddha Temple in Chiyadzwa. As if building their temple was not enough, they went further to invite President Robert Mugabe to officially open the temple in June 2012.Taken in this context, one can draw parallels between the initial colonisation strategy of the British who used the bible to conquer Zimbabwe .Thus it can be argued that China is using religion to inculcate its cultural norms and values thereby vividly bring out a horse and a rider relationship.

"We want to thank President Mugabe for allowing us the Chinese to follow and observe our culture in Zimbabwe, we are very grateful for his leadership qualities and we wish him longevity and good health," said Master Kai. (The Herald June 12, 2012).In this regard the possibility of cultural- imperialism should not be overemphasised. Furthermore, such stories that perceived China as a wolf in sheep's skin were ignored by the public media as it sought to over glorify the assumed benefits drawn from the relationship which existed between the two countries.

The public media were always there to counter any negative story that would seem to water down the efforts by the government in promoting the relations between the two countries. Thus when the private media view China as the new colonial master, The Herald and its sister publications, state owned television stations and radio stations would lucidly defend the government's decision to look 'East'. The Herald of 1 October 2012 carried an article titled China a'int colonising Zimbabwe. In the article, the paper presents China as the country's all weather friend. Thus The Herald maintains that the relationship between China and Zimbabwe is not of a horse and a rider but is hinged on a win-win situation where both partners would emerge winners in the process. Over and above that, it was argued that,

"The Sino-Zimbabwe relationship does not resemble colonialism. China's investment in Zimbabwe is based on win-win joint ventures that have benefited the country. The country is now realising dividends accrued 
from the win-win joint ventures". (The Herald October, 1, 2012)

Zimpapers together with ZBC were in the forefront of reporting about the deals signed between the two countries. They also focused on the official opening ceremonies of Chinese companies in Zimbabwe in various parts of the country. According to documentary evidence, the state owned media were reluctant to make a follow-up visits to the areas where Chinese companies were operating and hear what people would say. It seems the state owned media enjoyed relying on agenda setting press releases and continued to hail the partnerships between the two countries to the extent that they forgot their watchdog role as media organisations. This was evident in the contradictory reports that the papers from the Zimpapers stable, New Ziana and ZBC would produce as compared to the reality on the ground.

One of the major reasons that saw liberation fighters going to war against the former colonisers was unfair treatment of the black majority by the white minority at work and other important foras (Sithole 1979,160). According to the reports flooding the privately owned media, the same thing is happening again. Poverty -stricken black majority being ill-treated by the Chinese operating in their areas. After flooding Zimbabwean markets with cheap and sub-standard products thereby forcing many out of business, those Chinese nationals operating in mining and agricultural sectors seem not to be grateful hence they ill-treat workers and easily walking away with it.

Zimbabwe Construction and Allied Traders Workers Union (ZCATWU) secretary general Nicholas Mazarura said its members who were close to 12000 were subjected to inhuman treatment and were deprived of protective clothing by some of the Chinese companies. He further claimed that most complaints which the union received were from areas like Mahusekwa in Mashonaland East, where the Chinese were constructing a clinic, Warren Park in Harare where they were building schools, and companies along the Mazowe road.(The Zimbabwe Independent, December 23, 2010) The argument which can be drawn from such evidence reveal that Zimbabwe's relationship with China is just similar the coloniser-colony relationship it had with Britain.

Each private newspaper in Zimbabwe therefore seemed to have at least one or more sad stories about China's ill-treatment of workers in Zimbabwe. Although at some points the government promised to probe companies that were engaging in ill-practices, China continued to go unpunished. Again the public media turned a blind eye to most alleged scandals by China. Ironically, when the public media claim that China-Zimbabwe relations have benefited an ordinary man who got employment in the Chinese companies operating in Zimbabwe, the workers are petitioning the government seeking deportation of Chinese managers who are in the country. These might be early signs that slowly but surely Zimbabweans will sooner or later unite to chase their new colonial master.

The Standard reported that workers at Huawei Zimbabwe petitioned the co-ministers of Home Affairs, Theresa Makone and Kembo Mohadi urging them to deport senior company officials only identified as Wangzhigang and Yanyifan in the petition. The petition dated January 15, 2013 was also copied to the Minister of Labour and Social Services, Paurina Mpariwa, the Chinese Embassy and the Department of Immigration. "We, the undersigned hereby present this petition regarding the two Chinese members of Huawei Technologies Co Ltd (Zim Office)," reads part of the petition signed by 50 employees. "It is our contention that we cannot continue working with them because of their arrogance and ill-treatment of fellow local employees. We all content that their visas and/or work permits should be revoked forthwith". (The Standard, February, 3 2013). Drawing parallels of labour disputes of the 1960s in the colonial Zimbabwe where African nationalists were fighting against injustices at the workplace, China is sitting on a time-bomb hence the need to revisit the horserider relationship currently existing.

The NewsDay of March 21, 2011 carried a similar story titled Chinese ill-treating workers citing that hundreds of workers in Zvishavane were being underpaid. Those who would ask for pay increment were either beaten up, manhandled or threatened by dismissal from work. However, despite these being backward ways of dealing with workers in a globalising world, public media still invite the Zimbabwean nationals to draw good lessons from China. The Sunday Mail of January 28, 2012 had an article titled 10 lessons for Zimbabwe from China as if to claim that despite all her bad labour practices, China remains worth emulating from.

\section{Conclusion}

This paper argues that indeed a horse and a rider relationship is evident between China and Zimbabwe. Tracing the tenets of imperialism and progression of colonialism such as the initial stage whereby countries forge friendships characterised by promises, donations and contemporary exchange visits which usually benefit the coloniser, the Sino-Zimbabwe case is not an exception. Bilateral treaties like concessions signed by Lobengula King of the Ndebeles in Zimbabwe in the 1880s have already been witnessed between China and Zimbabwe. That has been followed by the Chinese coming to dominate the economy and controlling of the media terrain. In that context, they seized an opportunity to benefit from Zimbabwe's untapped resources. Thus, China perfectly wore the shoes of the former coloniser after the isolation, imposition of sanctions and souring of relations between Britain and Zimbabwe. In the same vein, the media has not been spared. China embarked on 
an array of strategies such as training of journalists, media management exchange programs, donating of digital broadcasting equipment and outside broadcasting vehicle equipment thereby gaining faith and loyalty of the public media. The seeming benefits are a by-product of an exploitative relationship. The available evidence from the private media indicates that the relations are gradually becoming sour. This is evidenced by the coverage of protests, strikes, demonstrations, xenophobic attacks, use of derogatory language/hate language referring to Chinese nationals and products such as Zhing-Zhong a term used to refer to dumped cheap substandard products. Having gone through several press reports from both private and publicly owned media in Zimbabwe, one would be persuaded to concur with the view that China has replaced Britain as Zimbabwe's new colonial power in a subtle manner unlike the forceful strategy displayed by Zimbabwe's former coloniser. Thus, this research informs the current Government of National Unity (GNU) of Zimbabwe to rethink its policy.

\section{References}

[1]. Burges, J. 2006. The Review of African Political Economy. Toronto: Routledge.

[2]. Frederikse, J. 1982. None But Ourselves: Masses vs Media in The Making of Zimbabwe. Harare: Zimbabwe Publishing House.

[3]. Habermas, J. 1989. The Structural Transformation of the Public Sphere. Cambridge: Polity Press.

[4]. Mathema, N.C.G. 2000. Newspaper in Zimbabwe. Lusaka: Multimedia Publications.

[5]. Mpofu, T. 2009. Total History, Southern African History. Harare: Priority Projects Publishing.

[6]. Mudyanadzo, W. 2011. Zimbabwe's Diplomacy 1980-2008. Gweru: Booklove Publishers.

[7]. Rusike, E.T.M. 1990. The Politics of the Mass Media: A Personal Experience. Harare

[8]. Thomson, A. 2004. An Introduction to African Politics. London: Routledge.

[9]. Prew, M. 1993. People Making History. Harare: Zimbabwe Publishing House.

[10]. Saunders, R. 1999. Dancing out of Tune: A History of The Media in Zimbabwe: Harare: Edwina Spicer Productions, Brylee Printers. [11]. Sithole, M. 1979. Zimbabwe Struggles Within the Struggle. Salisbury: Rujeko Publishers.

\section{JOURNAL ARTICLE}

[12]. Chari, T. 2011. Future Prospects of the print newspaper in Zimbabwe. Intellect 367-388.

\section{Newspapers}

[13]. http://www.herald.co.zw/index.php?option=com content\&view=article\&id=49341:xinhua-visits-zimpapers\&catid=37:topstories\&Itemid $=130$

[14]. http://www.newsday.co.zw/2011/03/21/2011-03-21-chinese-illtreating-workers/

[15]. http://www.theindependent.co.zw/2010/12/23/chinese-firms-under-probe-for-ill-treatment

[16]. http://www.thestandard.co.zw/2013/02/03/workers-petition-govt-over-abuse-by-chinese-employers/

[17]. http://news.xinhuanet.com/english/africa/2013-02/22/c 132186248.htm

[18]. www.herald.co.zw China ain't colonising Zim.htm

[19]. http://www.zimbabwesituation.org/?p=24247 